\title{
Organisational culture as a part in the development of open innovation - the perspective of small and medium-sized enterprises
}

"Competitors can never copy organisational culture" J. Bezos - Amazon .com

\section{Introduction}

The ability to introduce various concepts and business models is nowadays a prerequisite of the successful growth of enterprises' competitiveness. This is to a large extent closely linked to the ability of enterprises to create, implement and disseminate a variety of innovative solutions. Therefore, today the challenge is the use of open innovation (OI). This applies not only to large organisations, but also to small and medium-sized enterprises. In order to implement open innovation, small and medium-sized enterprises need to effectively manage their own growth through the preparation of appropriate strategies and the development of a model that encompasses all changes, taking into account a number of factors related to the growth dynamics of this sector. It is understood that an appropriate organisational culture plays an important

Katarzyna Szymańska, Ph.D. Lodz University of Technology, Faculty of Organisation and Management role in the implementation of innovation in this sector. There are many indications that a cultural mismatch and misunderstanding are the main reasons for major problems 
related to the low level of implementation of innovation by small and mediumsized enterprises. According to G. Aniszewska (2007, p.2), this is one of the reasons that can hinder the development of enterprises in the market. To be the driving force of the development of innovative small and medium-sized enterprises, organisational culture should be characterised by the elements related to innovativeness such as: a deliberate action aimed at inflow and outflow of knowledge in order to increase innovativeness of enterprises, the ability of enterprises to continuously expand their markets to use new solutions, the use of internal and external knowledge, flexibility of operation and transfer of knowledge to other entities. The main pillars of this sort of culture include (Disselkamp 2005, p. 67):

- professionalism, commitment, creativity, entrepreneurship and innovativeness, competitiveness,

- ability to quickly learn and acquire new skills,

- willingness to take risks and bear the responsibility,

- flexibility in thinking and action,

- ambition, enthusiasm, fighting spirit, initiative, success,

- ability to predict the future.

In Poland, unfortunately, quite often small and medium-sized enterprises do not have sufficient experience in the development of the so-called mature and technologically innovative organisational cultures characterised by the aforementioned features and values. Thus, the degree of the use of open innovation is also not high. It most often depends on the size of the company, the scale of innovation, the type of business activity, the duration of market presence and the geographical market. The reason for this state of affairs is often a lack of understanding of the role of organisational culture in the creation of pro-innovative activities.

The aim of the paper is to outline the issue of the impact of organisational culture on the development of the concept of open innovation in the sector of small and medium-sized enterprises. This objective was implemented successively by presenting the importance of organisational culture, describing the main principles of the concept of open innovation and attempting to define the term of open organisational culture. The results of the analysis of secondary sources as well as the author's own research experience indicate that the successful introduction of open innovation into the sector of small and mediumsized enterprises is inextricably linked with their organisational culture. Thus, the formation of a new type of culture, the so-called open organisational culture, is crucial. 


\section{The importance of organisational culture}

Although the issue of organisational culture is a quite frequent subject of scientific discussion, an insufficient number of publications that combine the term with the concept of open innovation can be seen. Thus, an attempt will be made to point out the main cultural determinants that may influence/ or not the development of the concept of open innovation in the sector of small and medium-sized enterprises. Each enterprise that operates in its own environment has its ideological foundations whose acceptance in the given social environment is a prerequisite for its effective functioning. According to Cz. Sikorski (2002a, p. 22), this is one of the perceptions of organisational culture which results in the definition that "organisational culture creates behaviours stemming from cultural norms that promote behaviours which are a result of formal norms of the organisation and which complement, modify or represent them, or constitute their complete opposite". It can be said therefore that each enterprise has its own organisational culture, and that it is the organisational culture which is a systemic feature of the organisation, creating a social system, and that the enterprise becomes organisational culture in the course of a complex process. Thus, organisational culture is understood as a common set of beliefs, values, norms and customs that control the behaviour of members of the organisation. It is specific to each organisation and shaped to a large extent by the management. Organisational culture is also reflected in the apparent, as well as hidden, dimensions of the organisation and determines patterns of learning and interpreting the reality undergoing constant change (Chong, Goh, Eze 2009, p. 89; Kulkarni, Ravindran, Freeze 2007, p. 63; Wong 2005, p. 32; Yeh, Lai, Ho 2006, p. 71).

An attempt to organise the concepts of organisational culture was made by L. Smircich (1983, 1987, pp. 339-358), who provided three possible methods of perception of this phenomenon. Firstly, according to this author, organisational culture is an independent variable, which is important for the study of the relationships existing between culture and the elements of the management process. From this perspective, it is an external factor that affects and influences the behaviour of the organisation's employees. Secondly, organisational culture should be treated as an internal variable, which is an element of the organisation affected by many other organisational elements. This culture will have a significant impact on the success of all activities undertaken by the organisation. Thirdly, organisational culture can be seen as an indigenous metaphor, in which the organisation is a culture. 
At this point, it should be noted that along with the development and dynamic transformations in the environment in which small and mediumsized enterprises operate, many changes occur, resulting in evolutionary or revolutionary change of their own organisational culture. Recognising this relationship underlines the understanding of organisational culture as a constantly ongoing, proactive process of constructing reality. Thus, it seems legitimate to say that the future of management of all organisations is related to their organisational culture. Often, making an attempt to explain a given phenomenon, one refers to culture, assuming that each organisation creates a specific culture whose elements, i.e. values, norms, behaviour patterns, symbols and myths, help to differentiate it from other organisations. These elements shape specific relationships between employees, between employees and the management as well as between the organisation and the environment, in response to the changes, allowing to distinguish members of one organisation from another. The above-mentioned principles - values - norms - attitudes form the main sequence of the components of organisational culture (Sikorski 2002 a, p. 24 ). The formation of organisational culture is therefore based on the deliberate modification of values and norms as well as the resulting patterns of behaviour, which should lead to new, cohesive and more effective - in these particular circumstances - transformations in the given organisational culture. This change applies to the relationships between the shaped values and the strategy as well the structure of the organisation, it also requires taking into account the culture of the society in which the organisation operates. Therefore, bearing this in mind, managers/owners must place emphasis on the relationship that exists between the success of the organisation and its organisational culture. Thus, using selected patterns of interpretation inherent in management concepts, one can consciously create cultures focused on the needs of the given organisation (Morgan 2006, p. 22). All these considerations confirm therefore that organisational culture underlies all key processes that occur in the given organisation, as it is an element which - when properly managed - can help the processes by being their "catalyst" or can hinder them. Thus, organisational culture must be regarded as the foundations of numerous interactions that enable the implementation of new concepts in enterprises of this sector.

Nowadays, in order to be competitive in the market, small and medium-sized enterprises must be characterised by the organisational culture directly oriented towards development processes, i.e. they have to create attributes associated with the broadening of knowledge, flexibility, creativity and, above all, openness to 
innovative changes (Zakrzewska-Bielawska 2011, p. 317). Numerous researchers of cultural norms point to these features as elements that support innovativeness of enterprises (Paliszkiewicz 2007, pp. 43-50; Martins, Terblanche 2003, pp. 64-74; Arad, Hanson, Schneider 1997, pp. 42-58; Matejuk 2005, p. 14; Purcarea, Benavides, Maria del Mar; Apetrei 2013, pp. 1096-1107).

The development of innovative organisational culture of small and medium-sized enterprises is affected by a number of external and internal factors. Internal factors include (Sikorski 2002 b, p. 74):

- personality traits of people that make up the given company,

- cultural traditions stemming from its history,

- existing organisational solutions,

- managers' impact.

Internal factors operate on the principle of interdependence, creating a specific organisational culture of small and medium-sized enterprises. The accumulation of external factors is a result of the impact of the entire dynamically changing environment in which enterprises in this sector function. Internal and external factors can have a constructive or destructive impact, dependent on the way small and medium-sized enterprises operate in their environment. The innovative development therefore requires a mature internal potential of the enterprise, which is its strength, that will allow it to take advantage of the potential offered by the external environment. This ability will enable enterprises to strengthen their response to the risks arising from the dynamics of the environment.

\section{Open innovation and an open organisational culture}

More than 23 million SMEs (2 million in Poland) operate nowadays in the European Union, constituting $99.8 \%$ of all businesses, employing almost $66 \%$ of all people employed in the private sector. The results of numerous studies point to the generally positive economic and social effects of their activities that translate into macroeconomic growth, increased innovativeness and the strengthening of competitiveness at the national and international level. Therefore, highly developed countries, business communities and non-profit organisations, as well as commercial entities, seek to support their development through various initiatives. Thus, for more than 20 years, innovation and innovativeness have come to be seen as a key source of business development, not only for large business organisations but also

Organisational culture as a part

in the development of open innovation -

the perspective of small and medium-sized

enterprises 
for small and medium-sized enterprises. Today, the ability to build innovative concepts and business models is the main step in development activities undertaken by small and medium-sized enterprises. The concept of open innovation (OI), which is one of the essential elements determining the level of innovativeness of enterprises (including small and medium-sized ones), is part of this trend. This points to the change in the paradigm of innovation, from the idea limited to the sole use of the enterprise's internal potential (closed innovation) to the concept based on the exchange of knowledge and new solutions between the enterprise and its environment (open innovation). The concept of open innovation (OI), which appeared in 2003, was introduced to the management sciences by $\mathrm{H}$. Chesbrough. According to the author, this concept is based on knowledge inflow and outflow: from the environment to the enterprise (inflow - exploration) and from the enterprise to the environment (outflow - the exploitation of the enterprise's own resources) for the sake of innovative development resulting in launching new products (services) onto the market (Chesbrough 2006, p. 17). This concept shows interdependences that exist between the individual elements on the basis of the feedback relationship. According to $\mathrm{H}$. Chesbrough, the model of open innovation involves the intentional use of flows of knowledge to accelerate internal innovation and entry to the market of external innovation. In addition, the paradigm assumes that enterprises can and should use external as well as internal ideas, striving to continuously improve their technology. According to H. Chesbrough (2006, p. 22), the model of open innovation is based on the following principles:

- innovative solutions can be found literary everywhere,

- company employees, small and medium-sized enterprises and universities are a valuable source of ideas for creating innovative solutions,

- innovative ideas must be also sought and acquired outside the enterprise,

- results of external R\&D can create significant value for the enterprise and its customers,

- conducting the enterprise's own research is not a prerequisite to be a beneficiary of commercialisation of technology,

- creating a better business model is more important than being first in the market,

- the best results are achieved using both the enterprise's own (internal) and other (external) ideas for innovative solutions,

- proper management of intellectual property is a key to success.

The main assumptions of model open innovation model are shown in figure 1. 


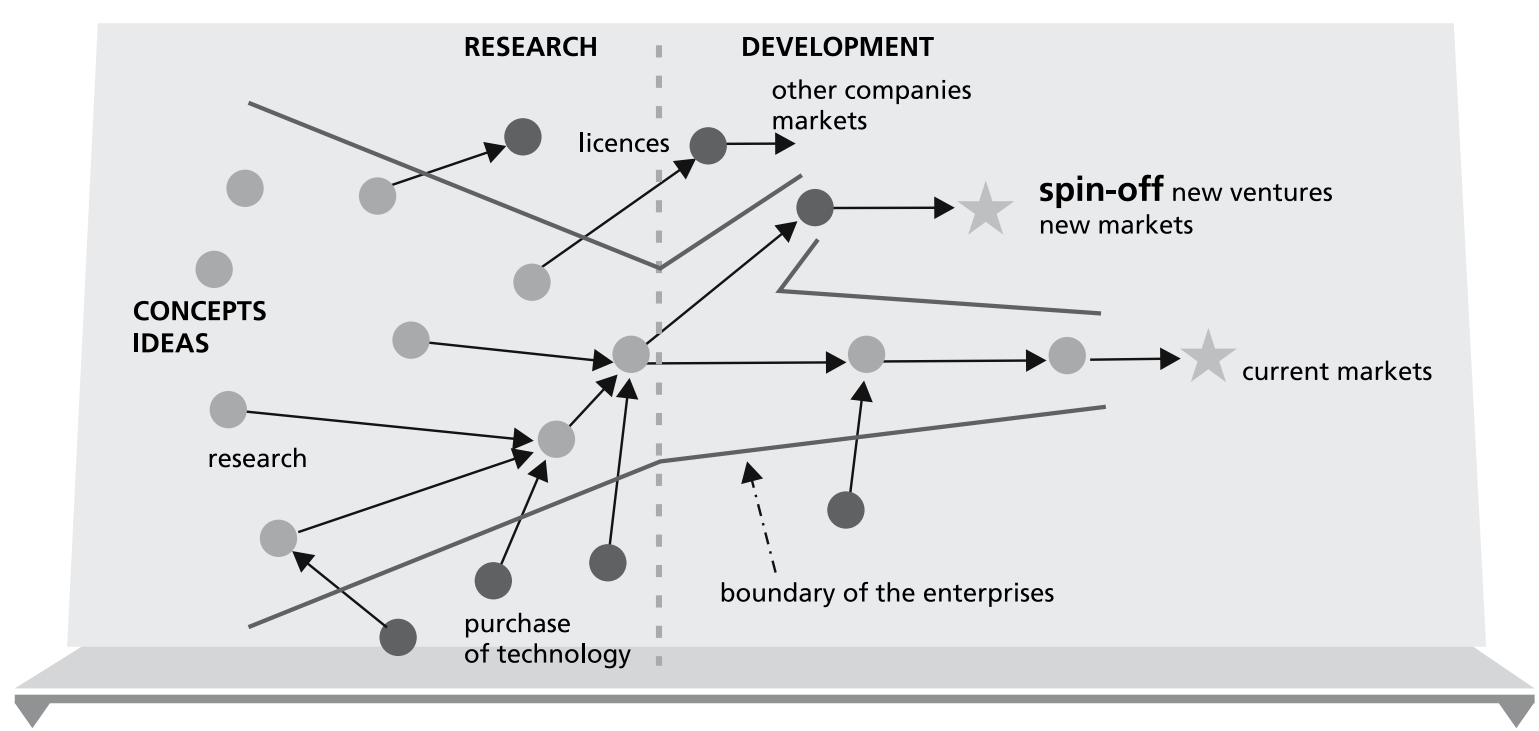

Figure 1. Open Innovation Model

Source: Santarek 2008, p. 37

B.S. Tether and A. Tajar (2008) perceive the OI trend only as a one-way knowledge transfer, related to the exploration of the environment (this is characteristic particularly in relation to small and medium-sized enterprises), in which generally ideas and concepts treated by other (external) organisations as ones of little value are obtained. Certainly, however, the OI concept is a valuable source of access to new resources and talents, providing enterprises with opportunities for learning and commercialisation of innovative solutions implemented in their environment that directly or indirectly influence the creation of a competitive advantage. The said exploration of the environment by small and medium-sized enterprises results mainly from a lack of available resources, thus a relatively low tendency of these entities to conduct their own R\&D activities, which is reflected mainly in their rather poor offer addressed to external partners, such as large organisations, universities, research centres, and other small and medium-sized enterprises. This situation is indicated by numerous studies conducted in this field (Adamik, Szymańska 2016, p. 6-7). Therefore, small and medium-sized enterprises should place special emphasis on cooperation with organisations in their environment that could support their own development, e.g.: within partnering networks that constitute a rich source of inspiration in the area of new technological solutions (Vrande, Jeroen de Jong, Vanhaverbrke, de Rochemont 2009, pp. 423-437). 
A departure from the concept of closed innovation (where the process of introducing innovative changes is subject to strict control within the organisation and is based on available internal resources) for the sake of open innovation can be seen (Stanisławski 2014, p. 173). It turns out that the superiority of the enterprise's market advantage is increasingly determined by the speed of deployment (aiming to keep ahead of the competition) rather than locking itself within its own organisational structure and conducting its own research (often stretched over time), which does not always guarantee market success.

Thus, it is necessary to encourage small and medium-sized enterprises to express even greater openness, manifested in cooperation and exchange of experience in the framework of various local or regional initiatives taking place between the sphere of business, science, public administration and even the society (Deering, Murphy 2003). In addition, the departure from closed models, which were often used in this sector, is a result of very dynamic changes in the environment. As a result, small and medium-sized enterprises should manifest openness in various layers of management, among others, in creating innovative concepts and business models. The development of innovation potential, however, is impossible without taking specific action. Moreover, innovation becomes a prerequisite in the situation of dynamic changes in the environment. The implementation of ideas and concepts also requires operating efficiency from this sector, i.e. the ability to translate the strategy into processes, systems and structures, as well as appropriate responses to unexpected situations. Studies also indicate that the other three factors are not sufficient if the enterprise is not characterised by a particular organisational culture. If an organisation seeks an increase in its efficiency and wants to prepare and go through a process of change, it is crucial to look at it from the perspective of the dominant organisational culture. Then, it is necessary to determine what cultural profile would be the most desirable and prepare a plan of action to modify the existing culture. Thus, changes of the traditionally perceived organisational culture of small and medium-sized enterprises leading towards the so-called open culture, i.e. the culture which integrates the enterprise's participants in this sector, namely owners, managers and employees, around innovative actions and the culture which will promote knowledge expansion, flexibility, creativity and, above all openness, become particularly important (Dobini 2008, p. 544).

For the purpose of the publication and the verification of the paper objectives, an attempt to define the term "open organisational culture" was made. An open 
organisational culture is the type of culture that is characterised by the socalled open space, which refers to the willingness to change (open innovation), high tolerance of uncertainty and flexibility of operation (Szymańska 2014, p. 530). Open space includes businesses activities related to the creation of broad networks of cooperation with the entire environment. This openness should therefore apply not only to customers, suppliers but also competitors, in fact, simply to enterprises that have complementary capabilities and do not hesitate to use them in cooperative relations with other sectors. Willingness to introduce innovative changes is associated with the ability of enterprises to incorporate and organise activities related to the occurrence of new factors in the environment in order to reduce the risk of making errors and take advantage of emerging opportunities. High tolerance of uncertainty will be associated with having adequate knowledge by both managers and employees explaining the given phenomenon which requires some sort of action or solution. 94\% of senior management representatives claim that people and organisational culture are the most important factor increasing innovativeness (Lou Gerstner, IBM- www.ibm.com/lvg/ access: 10.01.2016). Flexibility of operation is an important feature/trait of the modern enterprise which consciously and successfully deals with the situation of dynamic changes in the environment. As can be seen, the proposed definition of an open organisational culture is closely linked with the principles of open innovation. In this concept, what becomes particularly important is the process of change leading towards an open organisational culture which: fosters cooperation, provides freedom, is open to the environment, makes use of employees' potential, is tolerant of errors, is focused on the vision and the strategy, at the same time ensuring discipline, and integrates the enterprise's participants, i.e. owners, managers and employees, around new activities. An open organisational culture will therefore constitute "the backbone of every business", development, allowing to introduce the concept of open innovation in an adaptive manner. Simply put: "an open organisational culture equals open innovation". The key effect of these changes will therefore be the ability to introduce open innovation, and ultimately the desired business development.

\section{Conclusions}

The above-presented considerations lead to the conclusion that there is a close link between organisational culture and the level of absorption of open innovation in small and medium-sized enterprises. In order for this process to 
become an indicator of the success of entrepreneurial activity in this sector, all barriers must be eliminated and all available stimulants activated. To do this, an open organisational culture, which will motivate to innovate, needs to be built. This culture must be characterised by the focus on the development, commitment and dynamism on the part of all employees as well as by being integrated with the company's objectives, being pro-innovative, open to change and cooperation with the environment. It is therefore reasonable for organisational cultures of small and medium-sized enterprises to open up to the widely understood open innovation. This requires, however, for managers/the owner to notice opportunities provided by external determinants, at the same time creating internal opportunities generated by the enterprise itself. This depends largely on the degree of awareness of owners of small and medium-sized enterprises who should implement changes in this area in an evolutionary rather than revolutionary manner. To sum up, in order to be successful in the market, small and medium-sized enterprises need to strive to build an innovation-oriented and at the same time open organisational culture. Conducting further, in-depth studies assessing the impact of the existing organisational culture of the sector of small and medium-sized enterprises on their propensity for open innovation seems an interesting undertaking.

\section{Summary}

\section{Organisational culture as a factor in the development of open innovation - the perspective of small and medium-sized enterprises}

The ability to introduce various concepts and business models is nowadays a prerequisite of creating a competitive advantage. This is to a large extent closely linked to the ability of enterprises to create, implement and disseminate a variety of innovative solutions. Today the use of open innovation is a necessity. This applies not only to large organisations, but also to small and medium-sized enterprises. In order to implement open innovation, small and medium-sized enterprises need to effectively manage their own growth through the preparation of appropriate strategies and the development of a model that encompasses all changes, taking into account a number of factors related to the growth dynamics of this sector. It is understood that an appropriate organisational culture plays an important role in the implementation of innovation in the sector of small and medium-sized enterprises. There are 
many indications that a cultural mismatch and misunderstanding are the main reasons for major problems related to the low level of implementation of innovation by small and mediumsized enterprises. The aim of the paper is to outline the issue of the impact of organisational culture on the development of the concept of open innovation in the sector of small and mediumsized enterprises.

Keywords: $\quad$ organisational culture, open innovation, small and medium-sized enterprises.

\section{Streszczenie}

Kultura organizacyjna jako czynni rozwoju open innovation perspektywa małych i średnich przedsiębiorstw

Warunkiem kształtowania przewagi konkurencyjnej przedsiębiorstw jest dziś umiejętność wprowadzania różnych konceptów i modeli biznesowych. Duża większość z nich ściśle związana jest ze zdolnością przedsiębiorstwa do tworzenia, wdrażania i upowszechnienia różnych innowacyjnych rozwiązań. Koniecznością jest dziś stosowanie otwartych innowacji. Dotyczy to nie tylko dużych organizacji, ale także małych i średnich przedsiębiorstw. Aby małe i średnie przedsiębiorstwa wdrażały otwarte innowacje konieczne jest efektywne zarządzanie ich rozwojem przez przygotowanie odpowiednich strategii oraz opracowanie modelu wszelkich zmian przy uwzględnieniu wielu czynników odnoszących się do dynamiki ich rozwoju. Przyjmuje się, że istotną rolę we wdrażaniu innowacyjności w sektorze małych i średnich firm odgrywa odpowiednia kultura organizacji. Wiele bowiem wskazuje na to, iż istotną przyczyną głównych problemów związanych z niskim stopniem wdrażania innowacyjności do małych i średnich firm jest niedopasowanie i niezrozumienie kulturowe. Celem niniejszego opracowania jest przedstawienie zarysu problematyki wpływu kultury organizacyjnej na rozwój koncepcji open innovation w sektorze małych i średnich przedsiębiorstw.

Stowa

kluczowe: $\quad$ kultura organizacyjna, open innovation, mate i średnie przedsiębiorstwa. 


\section{References}

1. Adamik A., Szymańska K. (2016), The technological entrepreneurship capacity and partnering as elements of an open culture of small and mediumsized enterprises: case study of Poland, [in:] M.H. Bilgin, H. Danis, E. Demir (Eds.), Proceedings of the 15th Eurasian Business and Economics Society Conference, Springer, Lisbona, Seria: Eurasian Studies in Business and Economics, Vol. 3/1.

2. Aniszewska G. (2007), Kultura organizacyjna w zarządzaniu, PWE, Warszawa.

3. Arad S., Hanson A.A., Schneider R. (1997), A Framework for the Study of Relationships between Organizational Characteristics and Organizational Innovation, "The Journal of Creative Behaviour", Vol. 30, Issue 1.

4. Chesbrough H. (2006), Open business models: how to thrive in the new innovation land-scape, Harvard Business School Press, Boston.

5. Chong H.S., Goh G.G.G., Eze U.C. (2009), Knowledge management enablers toward successful new product development: A case study in a semiconductor manufacturing firm, "Journal of Knowledge Management Practice", no. 10(4); http:/ / www.tlainc.com/articl206.htm [access date: 10.09.2015].

6. Deering A., Murphy A. (2003), The Partnering Imperative. Making Business Partnership Work, John Wiley \& Sons, Chichester.

7. Disselkamp M. (2005), Innovationsmanagement: Instrumente und Methoden zur Umsetzung im Unternehmen, Gabler, Wiesbaden.

8. Dobini C. B. (2008), Measuring innovatin culture In Organizations. The development of a generalized innovation culture construct using exploratory factor analysis, "European Journal if Innovation Management", Vol. 11 (4).

9. https://hbr.org/product/ibm-corp-turnaround/an/600098-PDF-ENG (10.01.2016 -access date).

10. Kooiman J. (1999), Social Political Governance: Overview, Reflections and Design, "Public Management", No. 1 (1).

11. Kulkarni U.R., Ravindran S., Freeze R.A. (2007), Knowledge management success model: Theoretical development and empirical validation, "Journal of Management Information Systems", No. 23 (3).

12. Lachiewicz S., Matejun M., Walecka A. (2013), Przedsiębiorczość technologiczna w małych $i$ średnich firmach. Czynniki rozwoju, Wydawnictwo WNT, Warszawa.

13. Martins E.C., Terblanche F. (2003), Building Organizational Culture that Stimulates Creativity and Innovation, "European Journal of Innovation Management", Vol. 6, No. 1.

14. Matejuk J. (2005), Zarządzanie innowacyjne jako warunek konkurencyjności przedsiębiorstwa, "Zarządzanie Zmianami”, No. 2.

15. Morgan G. (2006), Images of organization, Sage, London.

16. Paliszkiewicz J. (2007), Kultura organizacyjna wspierająca innowacyjność $w$ matych $i$ średnich przedsiębiorstwach, "Acta Scientarum Polonorum Oeconomia", Wydawnictwo SGGW, No. 6 (1). 
17. Purcarea I., Benavides E., Maria del Mar; Apetrei A. (2013), Innovation and knowledge creation: perspectives on the SMEs sector, "Management Decision", Vol. 51, No. 5.

18. Santarek K. (2008), Transfer technologii z uczelni do biznesu. Tworzenie mechanizmów transferu technologii, Polska Agencja Rozwoju Przedsiębiorczości, Warszawa.

19. Sikorski Cz. (2002a), Zachowania ludzi w organizacji, PWN, Warszawa.

20. Sikorski, Cz. (2002b), Kultura organizacyjna, C.H. Beck, Warszawa.

21. Smircich L. (1983), Concepts of Culture and Organizational Analysis, "Administrative Science Quarterly", No 3.

22. Smircich L. (1987), Studying Organizations as Cultures, in: G. Morgan (ed.), Beyond Method: Strategies for Social Research, Sage, Beverly Hills - London - New Delhi.

23. Stanisławski R. (2104), Open innovation wśród matych iśrednich przedsiębiorstw jako instrument kształtowania przewagi konkurencyjnej, „Economics and Management", No. 2.

24. Strona internetowa: www.ibm.com/lvg/ access date: 10.01.2016.

25. Szymańska K. (2014), Otwarta kultura organizacyjna a innowacyjność matych i średnich przedsiębiorstw, [in:] A. Kaleta, K. Moszkowicz, L. Sołoducho-Pelc (eds.), Zarzadzanie strategiczne w teorii i praktyce, Wydawnictwo Naukowe Uniwersytetu Ekonomicznego we Wrocławiu, Wrocław.

26. Tether B. S., Tajar A. (2008), Beyond industry - university links: Sourcing knowledge for innovation from consultants, private research organizations and the public science-base, "Research Policy", Vol. 37, Issues: 6-7.

27. Van de Vrande V., Jeroen de Jong P. J., Vanhaverbrke W., de Rochemont M. (2009), Open innovation in SMEs: Trends, motives and management challenges, "Technovation", Vol. 29.

28. Wong K.Y. (2005), Critical success factors for implementing knowledge management in small and medium enterprises", "Industrial Management \& Data Systems", No. 105 (3).

29. Yang B. (2006), Learning organization, [in:] J. Greenhaus, G. Callanan (ed.), Encyclopedia of Career Development, Sage Publications, Thousand Oaks.

30. Yeh Y.J., Lai S.Q., Ho C.T. (2006), Knowledge management enablers: A case study, "Industrial Management \& Data Systems", No. 106 (6).

31. Zakrzewska-Bielawska A. (2011), Relacje między strategia a struktura organizacyjna w przedsiębiorstwach sektora wysokich technologii, Zeszyty Naukowe Politechniki Łódzkiej, No. 1095, Wydawnictwo Politechniki Łódzkiej, Łódź. 